\title{
Harmonic Mitigation in Traction Supply Substation Using Cascaded H-Bridge Converter
}

\author{
A. Awalludin, C. L. Toh \\ Department of Electrical Power Engineering, Universiti Tenaga Nasional, Malaysia
}

\begin{abstract}
Article Info
Article history:

Received Jun 5, 2018

Revised Aug 10, 2018

Accepted Aug 24, 2018

\section{Keyword:}

Cascaded H-bridge converter

Phase-shifted PWM

Phase-disposition PWM

Total harmonic distortion

ABSTRACT

The conventional three-level inverter has been proposed to act as a recuperating converter in Traction Supply Substation. This converter is mainly used to feed back the regenerative braking energy to the grid. However, passive filter is desired to mitigate the current and voltage harmonics. Therefore, this paper investigates the possibility to use a sevenlevel Cascaded H-Bridge (CHB) converter as the recuperating converter without additional filtering. The proposed converter is modeled with MATLAB/Simulink simulation software. It is then simulated with two potential modulation schemes, namely Phase-Shifted PWM (PS-PWM) and Phase-Disposition PWM (PD-PWM). The quality of AC waveforms produced by these two modulation methods is compared and studied. The results show that PS-PWM technique is preferable for this application as it offered a clean AC current waveform with less than 5\% harmonic distortion. However, a twenty-one-level CHB was predicted to comply with the $8 \%$ voltage harmonic requirement.
\end{abstract}

Copyright $(2) 2018$ Institute of Advanced Engineering and Science. All rights reserved.

\section{Corresponding Author:}

\author{
A. Awalludin, \\ Department of Electrical Power Engineering, \\ Universiti Tenaga Nasional, \\ Jalan IKRAM-UNITEN, 43000 Kajang, Selangor, Malaysia. \\ Email: azreen.awalludin@gmail.com
}

\section{INTRODUCTION}

Light Rail Transit (LRT) system is mainly developed to reduce traffic congestion problems in urban cities. It is used to transport passengers in an average speed of $70 \mathrm{~km} / \mathrm{hour}$. In general, an LRT train is powered up using DC electrification system via overhead line or ground level power supply system (third rail). Figure 1 (a) shows a typical configuration of a Traction Supply Substation (TSS) [1]. A unit of zigzag transformer and a twelve-pulse silicon diode rectifier are employed to convert the $33 \mathrm{kV}$ grid to DC supply rated at $750 \mathrm{~V}$ (nominal value). However, according to International Standard IEC1287-1, all equipment must stand for additional $20 \%$ of nominal voltage [2]. This is to ensure normal operation when a train enters braking mode. It has been documented that, the DC voltage level may achieve $900 \mathrm{~V}$ when a train is braking [3].

An electric train will work as a generator when it starts braking. The kinetic energy of a train is now transformed to electric energy [4]. If the train is designed with rheostatic braking capability, the regenerative braking energy will be dissipated through an on board rheostat. Alternatively, this regenerative braking energy may be drawn off via some parallel connected resistor banks at the conventional TSS. The main reason for not fully utilize the braking energy is due to the silicone diode rectifier only allows current to flow in one direction.

In order to fully utilize the regenerative braking energy, a recuperating converter can be employed. In [5], a three-level inverter is installed parallel to the twelve-pulse silicone diode rectifier. When the train starts braking, the inverter will be activated. Thus the braking energy can be delivered back to the AC grid. 
However, the inverter introduces current and voltage harmonics to the ac grid. Thus, some LC filters are implemented. On the other hands, an asymmetric Cascaded H-Bridge (CHB) converter has been proposed in [6]. The proposed system recruits three units of $\mathrm{H}$-bridge cell per phase. Each cell is coupled to an additional transformer unit. These transformers are designed with different turn ratio to produce a 27-level output voltage waveform. The total harmonics distortion is recorded less than $1 \%$. The power semiconductors are switched accordingly based on a specified look-up table.

The abovementioned proposals have recruited additional components to ensure the total harmonics distortion measurement complied with the industrial standard. These components include passive filters and additional transformers. With these components, the size and weight of the recuperating converter system will increase accordingly. Therefore, this paper proposes to use a symmetric Cascaded H-Bridge (CHB) converter as a recuperative converter in TSS (Figure 1 (b)). The total harmonics distortion produced by this $\mathrm{CHB}$ will be further investigated using two different modulation techniques. These modulation techniques include Phase-Shifted and Phase Disposition Pulse Width Modulation.

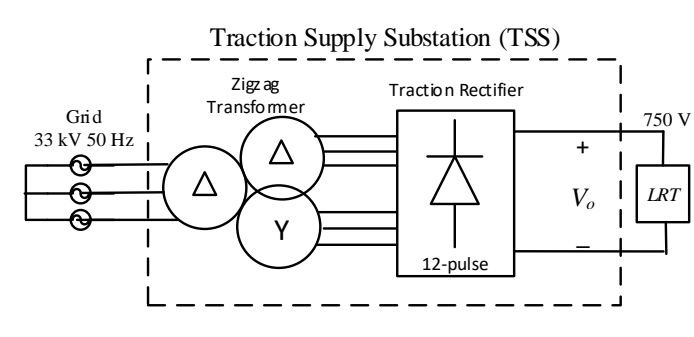

(a)

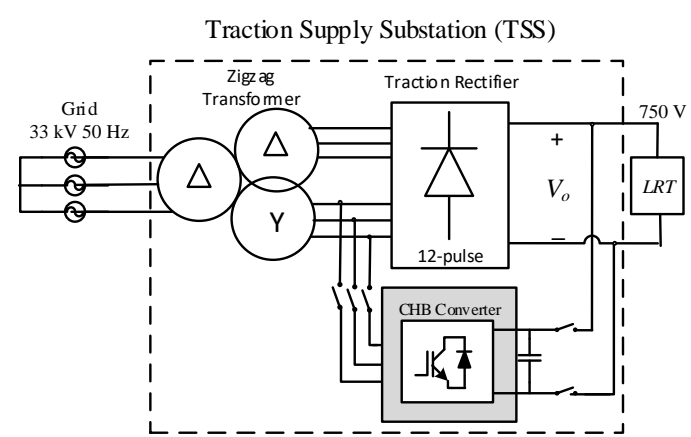

(b)

Figure 1. (a) Conventional Traction Supply Substation [1], (b) Proposed Cascaded H-Bridge (CHB) converter acts as recuperative converter in conventional Traction Supply Substation (TSS)

\section{CASCADED H-BRIDGE CONVERTER}

Cascaded H-Bridge (CHB) converters are widely used in medium and high voltage industrial applications which include HVDC [6], STATCOM [7], railway [8], and motor drives applications [9]. CHB is one of the classic multilevel converters other than Neutral Point Claimed (NPC) and Flying Capacitor (FC) converters [10]. It is documented that CHB converter has reached seventeen-voltage-level in the market. Besides, CHB converter uses lesser number of power semiconductors to generate same number of output voltage waveform compare to NPC and FC [11].

\subsection{Operational Principal}

The power circuit of a CHB converter is presented in Figure 2. A series of H-bridge cells (HC) are employed to produce staircase waveform at AC terminals. H-bridge cells are the key modules to construct a CHB converter. As shown in Figure 2 (b), the power circuit of H-bridge cell is equivalent to a single-phase inverter. There are four power switches (S1, S1', S2 and S2') connected in H-bridge configuration. These switches are then coupled to a floating capacitor (in parallel connection). The switching event for S1 and S1' must be complementary to each other. Figure 2 (c) shows the possible switching condition of a H-bridge Cell. With proper controlled of these power switches, a unit of $\mathrm{H}$-bridge cell will contribute three voltage levels $\left(+V_{c}, 0,-V_{c}\right)$ at the H-bridge cell terminal, $v_{H C}$. Thus, a phase voltage of CHB can be obtained by summing up all the $v_{H C}$ value in one phase leg. Equation (1) shows the general phase voltage equation.

$$
V_{p n}=\sum_{i=1}^{N} v_{H C_{p i}}
$$

where $p$ represents phase- $a$, phase- $b$ or phase- $c$; and $N$ is the total number of H-bridge cells configured in one phase leg. In order to produce balance three phase output voltages, $\mathrm{CHB}$ must employe equal number of $\mathrm{H}$ bridge cells for all phase legs. The number of output voltage levels, $m$, can be estimated with (2). 


$$
m=2 N+1
$$

where $N$ is the total number of $\mathrm{H}$-bridge cells connected in one phase leg.

The modular structure of $\mathrm{CHB}$ converter increases the availability and flexibility to reach higher voltage level using low voltage semiconductors. By increasing the number of $\mathrm{H}$-bridge cells, the Total Harmonics Distortion (THD) of currents and voltages can be further reduced [11]. Besides, some redundant $\mathrm{H}$-bridge cells can be added to improve the converter reliability [9]. Although CHB offers many advantages by hiring more H-bridge cells, the complexity of its power circuit and controller design will increase proportionally. Thus, a seven-level CHB is first selected for this study. Three units of $\mathrm{H}$-bridge cells will be employed per phase leg $(N=3)$.

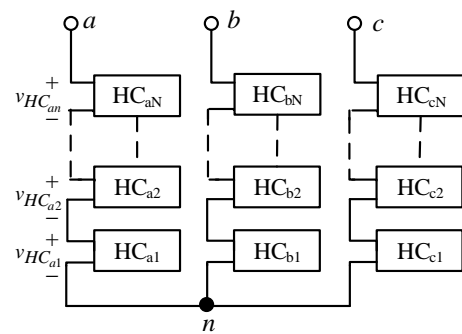

(a)

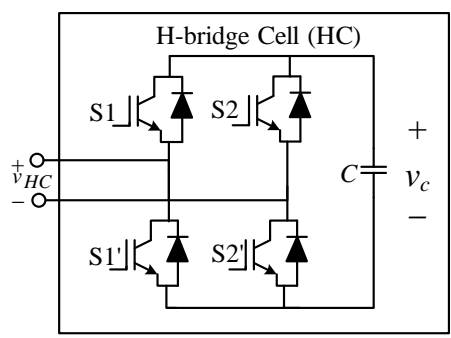

(b)

\begin{tabular}{|ccc|}
\hline S1 & S2 & $v_{H C}(\mathrm{~V})$ \\
\hline ON & OFF & $+V_{c}$ \\
OFF & OFF & 0 \\
ON & ON & 0 \\
OFF & ON & $-V_{c}$ \\
\hline
\end{tabular}

(c)

Figure 2. Power circuit of (a) Cascaded H-Bridge converter, (b) H-bridge Cell, (c) Switching condition versus $\mathrm{H}$-bridge cell output voltage level, $v_{H C}$

\subsection{Modulation Techniques}

Symmetric Cascaded H-Bridge converter has been investigated with different types of modulation techniques, such as Space Vector Modulation (SVM) [12], Selective Harmonic Elimination (SHE) [7],[13], Selective Harmonic Mitigation (SHM) [14], and Sinusoidal Pulse Width Modulation (SPWM) [15],[16]. Among all, SPWM technique is simpler to be implementated [17]. A sinusoidal wave (control signal) is compared with a series of high frequency triangular waves to generate specific gating signals. SPWM method is further divided into Phase-Shifted PWM, Phase-Disposition PWM, Phase Opposition PWM, and Alternate Phase Opposition PWM [18].

\subsection{Phase-Shifted Pulse Width Modulation (PS-PWM)}

Phase-Shift PWM (PS-PWM) method had been commercially applied to CHB converter [10]. This technique uses $N$ pairs of triangular waveform $\left(v_{t r i} P S_{i}\right.$ and $\left.-v_{t r i} P S_{i}\right)$ to control $N$ number of H-bridge cells per phase leg. These triangular waves are set to same amplitude and identical frequency (in kHz range). Thus, the amplitude and frequency modulation indexes, $m_{a}$ and $m_{f}$ are formulated as follows:

$$
\begin{aligned}
& m_{a}=\frac{\hat{V}_{\text {sine }}}{\hat{V}_{\text {tri_ } P S_{1}}} \\
& m_{f}=\frac{f_{\text {tri }}}{f_{\text {sine }}}
\end{aligned}
$$

Figure 3(a) illustrates PS-PWM scheme for a seven-level CHB converter in phase-a [15]. Three dominant triangular waves, namely $v_{t r i_{-} P S_{1}}$ to $v_{t r i_{-} P S_{3}}$ are arranged in sequence with a phase delay angle, $\theta$, of $60^{\circ}$ apart from each other. The phase delay angle, $\theta$, is basically derived from:

$$
\theta=\frac{180^{\circ}}{N}
$$


By assuming that the capacitor voltage, $V_{c}$, value is constantly fixed in all the H-bridge cells, a pair of triangular wave, $v_{t r i_{-} P S_{i}}$ and $-v_{t r i_{-} P S_{i}}$ is used to control $H C_{p i}$. As shown in Figure 3 (a) ii. - Figure 3 (a) iv., the $-v_{t r i_{-} P S_{i}}$ wave is produced by inversely duplicating the dominant $v_{t r i_{-}} P S_{i}$ waveforms. The switching conditions are given in (6) and (7). The power switch $\mathrm{S} 1$ is controlled by comparing the sinusoidal wave with the dominant $v_{t r i} P S_{i}$ waveform. Whereas, S2 is triggered on when the pairing triangular wave, $-v_{t r i} P S_{i}$ is greater than the sinusoidal wave.

$$
\begin{aligned}
& \mathrm{S} 1 \text { of } H C_{p i} \text { are triggered } \mathrm{ON} \text { when } v_{\text {sine }}>v_{t r i_{-}} P S_{i} \\
& \mathrm{~S} 2 \text { of } H C_{p i} \text { are triggered } \mathrm{ON} \text { when } v_{\text {sine }}<-v_{\text {tri_ }} P S_{i}
\end{aligned}
$$

where $p$ represents phase- $a$, phase- $b$ or phase- $c$; and $i$ iterates from $1,2, \ldots, N$.

The output voltage waveform, $v_{H C_{a i}}$ of each H-bridge cell is triggered between +1 p.u. and -1 p.u., which is equivalent to $+V_{c}$ and $-V_{c}$. By adding up $v_{H C_{a 1}}, v_{H C_{a 2}}$ and $v_{H C_{a 3}}$, a seven-level phase-a output voltage waveform is generated as shown in Figure 3 (a) v. The peak-to-peak output phase voltage is stepping up from $-3 V_{c}$ slowly to reach $+3 V_{c}$.

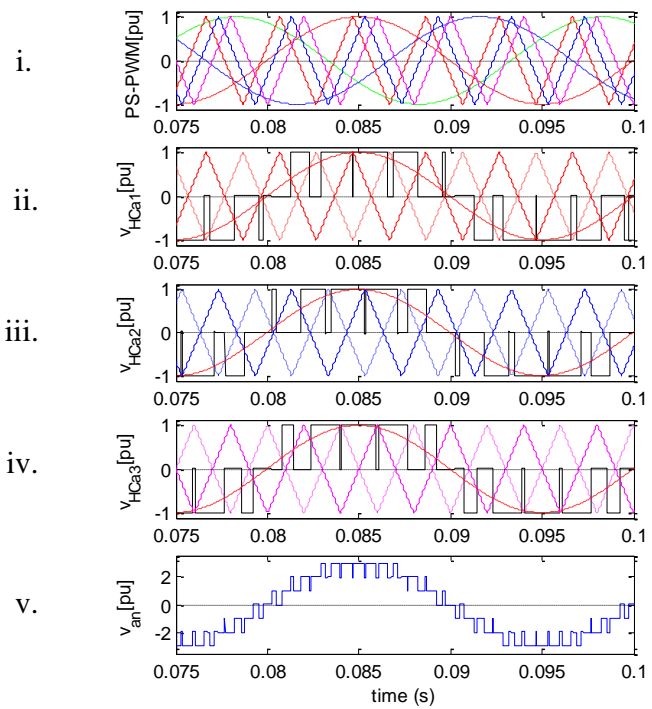

(a)
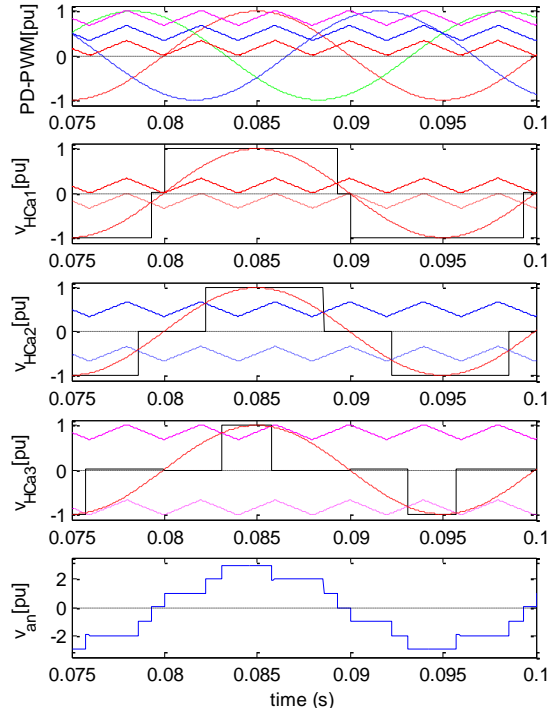

(b)

Figure 3. Pulse Width Modulation in CHB converter which employs three units of H-bridge cell, (a) PhaseShifted PWM [15], (b) Phase-Disposition PWM

\subsection{Phase-Disposition Pulse Width Modulation (PD-PWM):}

In Phase-Disposition PWM (PD-PWM), $N$-pairs of triangular wave $\left(v_{t r i_{-}} P D_{i}\right.$ and $\left.v_{t r i} P D_{(N+i)}\right)$ are also demanded to control $N$ numbers of H-bridge cell in a CHB converter. Figure 4 (b) i. illustrates the PDPWM method with three dominant triangular waves namely $v_{t r i} P D_{1}$ to $v_{t r i_{-}} P D_{3}$. These triangular waves are set with same amplitude and frequency. In general, the amplitude ratio of each carrier wave, $\hat{V}_{t r i} P D_{i}$, is equally divided by the total number of $\mathrm{H}$-bridge cells as described in (8).

$$
\hat{V}_{t r i_{-} P D_{i}}=\frac{1}{N}
$$


The dominant triangular waves, $v_{t r i} P D_{i}$ are stacked up using (9). Whereas, the pairing triangular wave, $v_{t r i} P D_{(N+i)}$, is shifted vertically down using (10).

$$
\begin{aligned}
& v_{t r i \_P D_{i}}=v_{t r i_{-} P D_{1}}+\left((i-1) \times \hat{V}_{t r i_{-} P D_{1}}\right)
\end{aligned}
$$

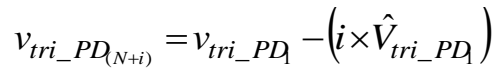

The amplitude modulation index, $m_{a}$, must set to less than 1 using (11). This is to ensure that the CHB converter always operates in linear modulation mode.

$$
m_{a}=\frac{\hat{V}_{\text {sine }}[\mathrm{p} . \mathrm{u}]}{\sum_{i=1}^{N} \hat{V}_{\text {tri_PD }}}
$$

The frequency modulation index, $m_{f}$, can be calculated using (4).

By assuming that each H-bridge cell always maintains a constant $V_{c}$ value, this paper will simplify the explanation by nominating $v_{t r i_{-} P D_{i}}$ and $v_{t r i_{-} P D_{(N+i)}}$ to control power switches in $H C_{p i}$.

$$
\begin{aligned}
& \mathrm{S} 1 \text { of } H C_{p i} \text { are triggered } \mathrm{ON} \text { when } v_{\text {sine }}>v_{t r i_{-} P D_{i}} \\
& \mathrm{~S} 2 \text { of } H C_{p i} \text { are triggered } \mathrm{ON} \text { when } v_{\text {sine }}<v_{t r i_{-} P D} D_{(N+i)}
\end{aligned}
$$

where $p$ represents phase- $a$, phase- $b$ or phase- $c$; and $i$ iterates from $1,2, \ldots, N$. Figure 3(b) ii. - Figure 3(b) iv. present the PWM in each H-bridge cell together with its relevant ouput voltage waveform, $v_{H C_{a i}}$. Similary, each H-bridge cell produces three-level of voltage waveforms. By summing up the voltage waveforms of $v_{H C_{a 1}}$ to $v_{H C_{a 3}}$, a seven-level phase-a output voltage waveform is produced (Figure 3 (b) v.).

\section{SIMULATION VERIFICATION}

A seven-level Cascaded H-Bridge (CHB) converter is modeled using MATLAB/Simulink. The simulation model is used to study the AC waveforms quality with two different modulation techniques which are described in Section 2.2. The total harmonic distortion of AC waveforms are measured with the MATLAB Powergui FFT Analysis Tool.

\subsection{Simulation Model}

Figure 4 (a) shows the CHB converter simulation model. The $33 \mathrm{kV}$ grid and the zigzag transformer are modelled as a balanced three-phase RL-load in this simulation. The RL-load values are set by try and error to meet the braking current level given in [1]. Nine units of H-bridge cells are employed. They are evenly distributed in phase leg-a, phase leg-b and phase leg-c. Figure 4 (b) shows the power circuit of Hbridge cell. Four units of IGBT switches are connected in H-bridge configuration. The capacitor, which supposes to be connected in parallel to the H-bridge power switches is modeled as a constant dc source. The dc source is set to $300 \mathrm{~V}$. This paper assumed that the traction network will hold up to $900 \mathrm{~V}$ (DC link voltage, $V_{d c}$ ) when a train is braking. The $V_{d c}$ is equally divides by three units of H-bridge cell per phase.

Figure 4(c) and 4(d) illustrate the PS-PWM and PD-PWM simulation models for controlling the Hbridge cells used in phase-a. These blocks are duplicated for others phase-leg by introducing phase-b and phase-c sinusoidal waves as the control signals. The amplitude of all sinusoidal waves are set to $0.545 \mathrm{~V}, 50$ $\mathrm{Hz}$. They are programed to be apart from each other with $120^{\circ}$ phase shift. The amplitude modulation index, $m_{a}$ is set to 0.545 , mainly to ensure that the effective value of the produced line-line voltages will achieve $585 \mathrm{~V}$ [1]. This voltage level is documented as the rated norminal voltage at secondary winding of the zigzag transformer. 
The triangular carrier waves are set to $1050 \mathrm{~Hz}$ for both PWM schemes. In PS-PWM, the amplitude of the dominant carrier waves (Triangle 1 to Triangle 3 ) are all set to $1 \mathrm{~V}$ with a $60^{\circ}$ phase shift. Whereas, PD-PWM limits the amplitude of the six triangular waves to $1 / 3 \mathrm{~V}$. These carrier waves do not have phase delay. All simulation parameters are summerized in Table 1.

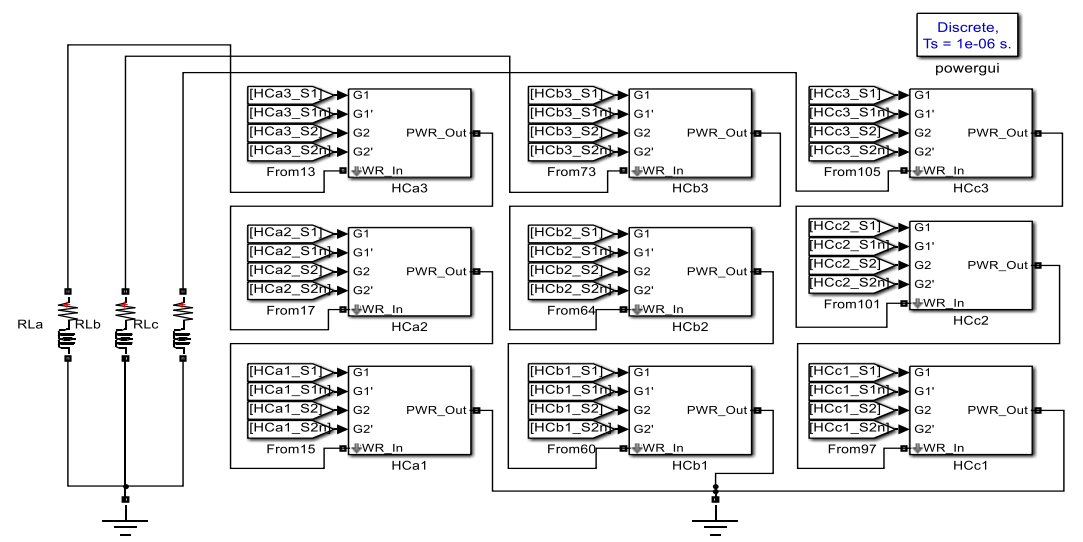

(a)

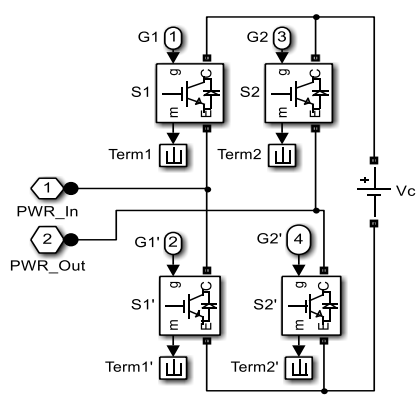

(b)

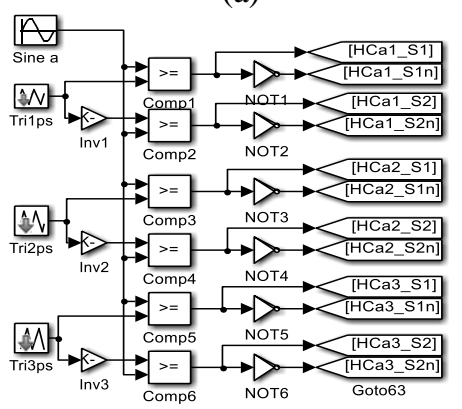

(c)

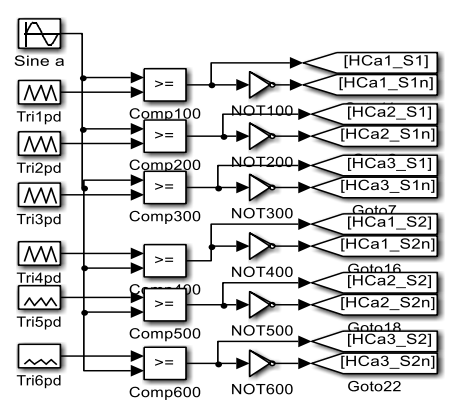

(d)

Figure 4. Simulation model: (a) Cascaded H-Bridge (CHB) Converter, (b) Power circuit of a H-bridge Cell (HC), (c) PS-PWM, (d) PD-PWM

Table 1. Simulation Parameters

\begin{tabular}{lcccc}
\hline \multicolumn{2}{c}{ Cascaded H-Bridge (CHB) Converter Parameters } & Pulse-Width Modulation parameters & $\begin{array}{c}\text { PS- } \\
\text { PWM }\end{array}$ & $\begin{array}{c}\text { PD- } \\
\text { PWM }\end{array}$ \\
\hline Number of H-bridge Cell per phase, $N$ & 3 & Amplitude Modulation Index, $m_{a}$ & 0.545 & 0.545 \\
Capacitor voltage level per H-briege Cell, $V_{c}$ & $300 \mathrm{~V}$ & Frequency Modulation Index, $m_{f}$ & 21 \\
Resistive Load per phase, $R$ & $0.3 \Omega$ & Triangular waves phase delay angle, $\theta_{\text {tri_PS }}$ & $60^{\circ}$ & $0^{\circ}$ \\
Inductive Load per phase, $L$ & $50 \mu \mathrm{H}$ & Amplitude ratio of triangular waves, $\hat{V}_{\text {tri_ } P D_{i}}$ & 1 \\
\hline
\end{tabular}

\subsection{Simulation results}

Both modulation methods, PS-PWM and PD-PWM are evaluated through simulations. The simulation results are presented side by side for comparison. The simulation results of PS-PWM is compiled in column (a) while column (b) reserved for PD-PWM. The simulation results of phase-a are only presented in Figure 5 and Figure 6 with full discussion. Identical results are observed repeatedly in phase-b and phasec. In addition, three-phase voltages and current waveforms are illustrated in Figure 7. Lastly, Figure 8 displays a set of THD measurements of the CHB converter simulated with different numbers of $\mathrm{H}$-bridge cells per arm.

A series of triangular carrier waves and a modulating wave are presented in Figure 5 . A $50 \mathrm{~Hz}$ sinusoidal waveform is clearly shown in Figure 5 i. The peak value of this sinusoidal wave is captured slightly above $0.5 \mathrm{~V}$ level in the zoom-in view of Figure 5 ii. These figures confirmed the modulation index, $m_{a}$, has been set accordingly. The dominant triangular waves are plotted using solid line with its pairing carrier waves presented in dotted line for both modulation techniques. As shown in Figure 5 (a) ii., the triangular waves of PS-PWM are set to $2 \mathrm{~V}$ peak-to-peak and shifted horizontally $\left(60^{\circ}\right)$ in sequence. On the 
other hand, the PD-PWM employs six identical carrier waves with an amplitude of 1/3 V peak-to-peak. As shown in Figure 5 (b) ii., these signals are shifted vertically using (9) and (10).
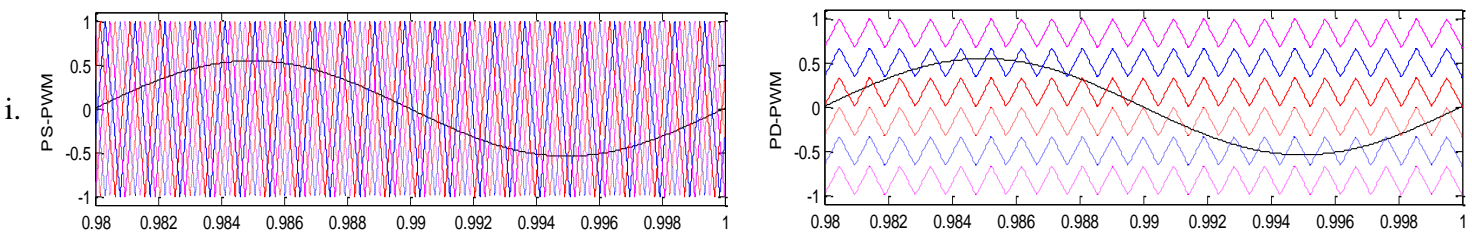

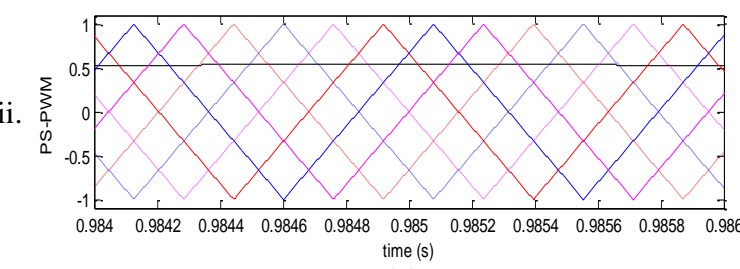

(a)

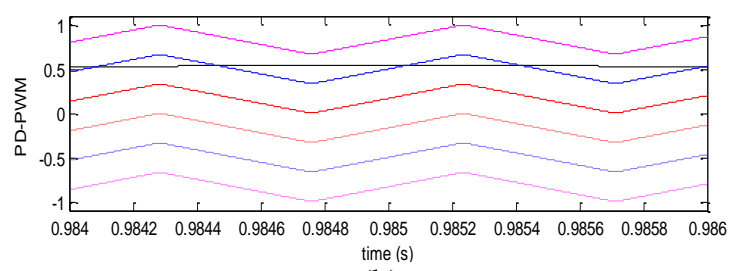

(b)

Figure 5. Simulation results for (a) PS-PWM, (b) PD-PWM. The sub-plots show: i. triangular carries with one complete cycle of modulation signal, ii. Zoom-in view of triangular waves

When the CHB converter is simulated with PS-PWM scheme, all H-bridge cells are being actively triggered. The sinusoidal wave is fully modulated by three pairs of the triangular waves. As a result, each of the H-bridge cells produces a three-level output voltage waveform as shown in Figure 6 (a) i. - iii. All the $v_{H C_{a i}}$ keep toggling between $300 \mathrm{~V}, 0 \mathrm{~V}$, and $-300 \mathrm{~V}$. The power are evenly distributed among three $\mathrm{H}$ bridge cells in each phase leg. However, in PD-PWM method, only H-bridge Cells, $H C_{a l}$ and $H C_{a 2}$ produce three-level output voltages, the $H C_{a 3}$ constantly generates zero voltage level as shown in Figure 6 (b) i. - iii. The third unit of H-bridge cell is inactive countinuously because the third pair of the carrier waves swing above the modulating wave. Figure 5 (b) recorded that $v_{t r i} P D_{3}$ swings from $0.667 \mathrm{~V}$ to $1 \mathrm{~V}$ while its pairing carrier oscilates between $-0.667 \mathrm{~V}$ and $-1 \mathrm{~V}$. The switching events occur in CHB converter using PD-PWM is much lower compare to PS-PWM scheme.

Theorectically, a CHB converter with three units of H-bridge cell per phase, should generate a seven-level output voltage waveform. However, as the amplitude modulation index, $m_{a}$ is set to 0.545 , a fivelevel phase voltage waveform is observed at the AC terminals for both modulation techniques. Figure 6 iv. shows the phase voltage, $v_{a n}$, is toggled between $300 \mathrm{~V}$ to $600 \mathrm{~V}$ when the modulating signal reaches its peak around $0.985 \mathrm{~s}$.

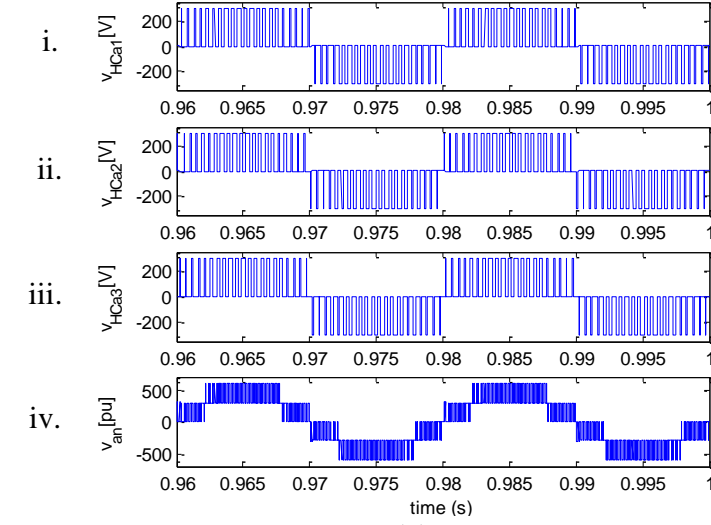

(a)
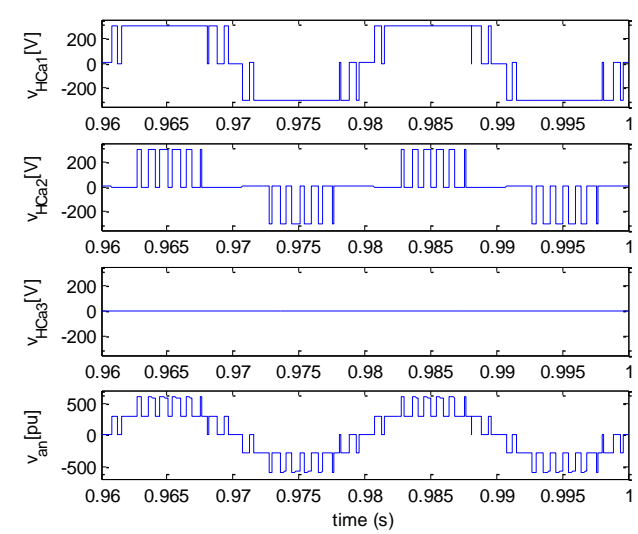

(b)

Figure 6. Simulation results for (a) PS-PWM, (b) PD-PWM. The sub-plots shows the output voltage waveforms for H-bridge Cells: i. $\mathrm{HC}_{\mathrm{a} 1}, v_{H C_{a 1}}$, ii. $\mathrm{HC}_{\mathrm{a} 2}, v_{H C_{a 2}}$, iii. $\mathrm{HC}_{\mathrm{a} 3}, v_{H C_{a 3}}$ and iv. phase-a voltage waveform, $v_{a n}$ 
Figure 7 i. presents the phase voltage waveforms for each leg. The simulation results prove that a balance three-phase output voltage waveforms are produced. All phase voltage waveforms are presented in staircase-wave pattern in five levels. The maximum and minimum output voltage level is captured as $+600 \mathrm{~V}$ and $-600 \mathrm{~V}$. Three-phase current waveforms are recorded in Figure 7 ii. The phase currents are tuned to reach $\pm 2 \mathrm{kA}$ mainly to illustrate the maximum braking current produced by a train. As comparing these two modulation techniques, PS-PWM produces a better quality ac currents. Figure 7 iii. depicts one of the line-toline voltage waveform, $v_{a b}$. The effective value of the fundamental component for both voltage waveforms are noted as $589 \mathrm{~V}$, which is very closed to the nominal value of the secondary winding of the rectifier transformer. PS-PWM technique generates a nine-level voltage waveform. The peak voltage value reaches $\pm 1200 \mathrm{~V}$. On the other hand, PD-PWM method produces a seven-level line-to-line voltage waveform with less distortion.

i.

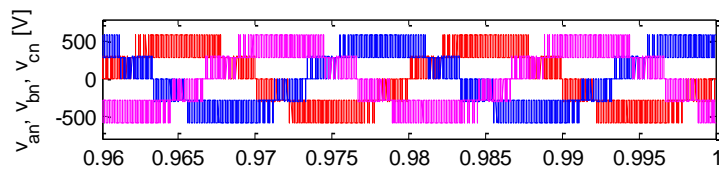

ii.
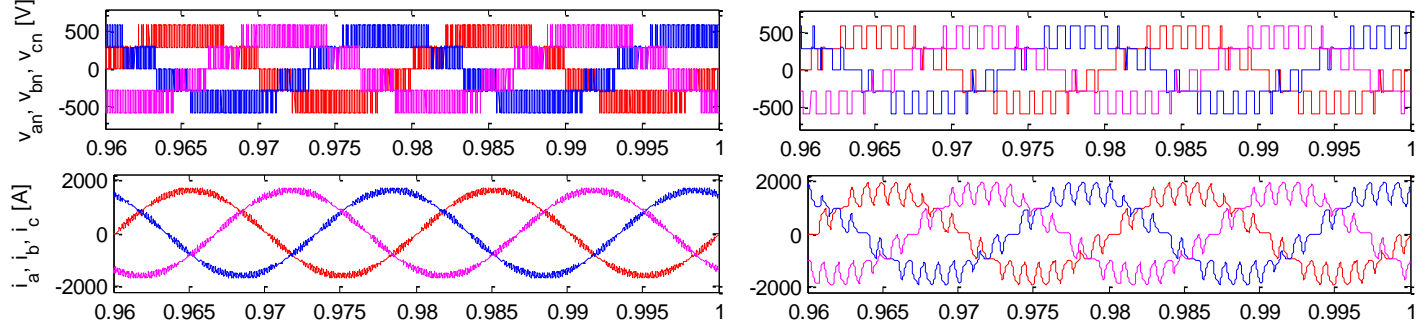

iii.

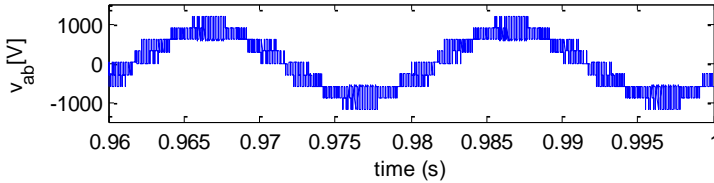

(a)

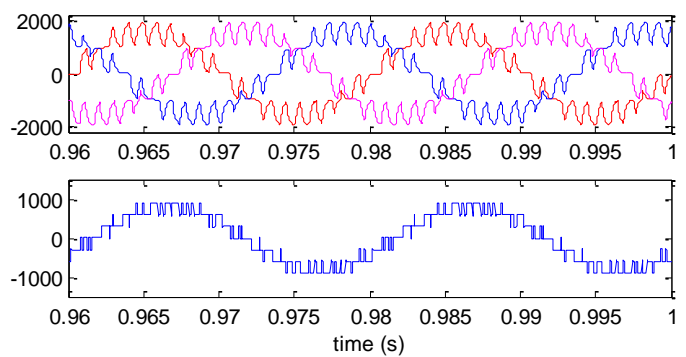

(b)

Figure 7. Simulation results for (a) PS-PWM, (b) PD-PWM. The sub-plots show: i. phase voltage waveforms, ii. phase current waveforms, and iii. line-to-line voltage, $v_{a b}$, waveform

Referring to the IEEE Standard [19], the acceptable Total Harmonics Distortion (THD) for current and voltage are recomended to keep below $5 \%$ and $8 \%$ respectively. From the above simulation, $\mathrm{THD}_{i}$ of the PS-PWM method meets the IEEE Standard, with $4.85 \%$ distortion. However, the line-to-line voltage waveform is badly distorted as high as $30.28 \%$. To further study the reduction of harmonics, simulations are carried out by increasing the number of H-bridge cells in the CHB converter. Figure 8 presents a set of current and voltage harmonics measurement (in percentage) versus different number of $\mathrm{H}$-bridge cells per phase leg. The dotted line represents the THD requirements given in IEEE Standard. The line-to-line voltage harmonic finally achieves $7.76 \%$ when the CHB is simulated with PD-PWM method with eight units of Hbridge cells integrated in each phase leg. Although the $\mathrm{THD}_{i}$ is exponentially reducing, PD-PWM still produces a slightly greater harmonic distortion compare to PS-PWM method. Hence, the CHB converter is more suitable to be modulated using PS-PWM technique as it offers excellent quality of current waveforms. To cope with the voltage harmonics requirement, more H-bridge cells are required to expanse the voltage levels. It is predicted that twenty-one-level of $\mathrm{CHB}$ converter may be constructed as the recuperating converter in future traction supply substation.

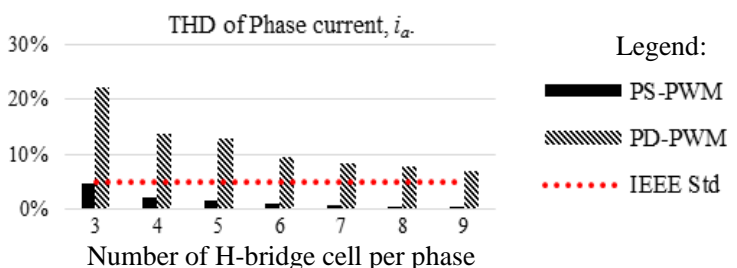

(a)

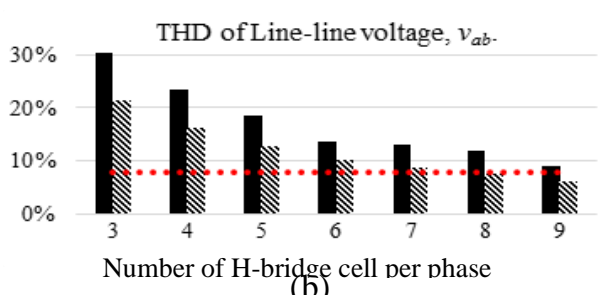

(b)

Figure 8. CHB converters with increasing number of H-bridge cell: (a) Phase current harmonics comparison between PS-PWM and PD-PWM, (b) Line-line voltage harmonics comparison between PS-PWM and PD-PWM 


\section{CONCLUSION}

The current applicable recuperating converter system produced high harmonic current and voltage to the grid. Consequently, passive filters must be installed accordingly to ensure the current and voltage harmonics comply with the industrial standard. This paper presents a study to investigate the possibility of implementing a Cascaded H-Bridge converter as a recuperating converter without additional filtering elements. The objective of this paper is to minimize the current and voltage harmonics with an appropriate modulation technique.

The operational principal of the CHB converter has been presented together with two modulation schemes (PS-PWM and PD-PWM). A CHB converter is then being modelled and simulated. Simulation results for each modulation method had been presented with full analysis. The simulation results shows that PD-PWM produces $22 \%$ and $21 \%$ of current and voltage harmonics at AC terminals. On the other hand, PSPWM has offerred extremely low distortion in phase current, about $5 \%$ of harmonic distortion is recorded. Unfortunately, the line-line voltages are badly distorted with $\mathrm{THD}_{v}$ captured as $30 \%$.

In order to reduce the voltage harmonic distortion without passive filters, the number of $\mathrm{H}$-bridge cells can be added to expanse the output voltage level. A study on predicting the required number of $\mathrm{H}$ bridge cells of the CHB has been conducted. It is estimated that, a twenty-one-level of CHB with PhaseShifted Pulse Width Modulation (PS-PWM) method may keep the voltage harmonics distortion close to $8 \%$ (IEEE Standard)

\section{ACKNOWLEDGEMENTS}

The authors are pleased to express their appreciation to the Ministry of Higher Education (MOHE), Malaysia for sponsoring the Fundamental Research Grant Scheme (FRGS) to conduct this research.

\section{REFERENCES}

[1] M. Rajaratnam, et al., "Plan of Instruction - Traction Power Sub-Station (TPSS) Overall System Description," Konsortium CMC-COLAS-UNIWAY, 2016.

[2] V. Gelman, "Comparison between wayside storage and Reversible Thyristor Controlled Rectifiers (RTCR) for heavy rail applications," The 2013 Joint Rail Conference, pp. 1-10, 2013.

[3] R. Vial, et al., "Simulating calculations and optimization design of a new HVDC supply power for light rail system," 36th Annual Conference on IEEE Industrial Electronics Society, Glendale, pp. 2364-2369, 2010.

[4] S. Xie, et al., "Study on simulation traction load with regenerative braking," Energy Procedia, vol. 14, pp. 12991304, 2012.

[5] W. A. G. de Jager, et al., "Implementation of active regeneration unit in a traction substation," 16th European Conference on Power Electronics and Applications, pp. 1-9, 2014.

[6] B. Alamri and M. Darwish, "Power loss investigation in HVDC for Cascaded H-Bridge Multilevel Inverters (CHBMLI)," IEEE PowerTech, pp. 1-7, 2015.

[7] W. Song and A. Q. Huang, "Fault-tolerant design and control strategy for cascaded H-bridge multilevel converter based STATCOM," IEEE Trans. on Inds. Elect., vol/issue: 57(8), pp. 2700-2708, 2010.

[8] J. Dixon and L. Moran, "A clean four-quadrant sinusoidal power rectifier using multistage converters for subway applications," IEEE Trans. on Ind. Electronics, vol/issue: 52(3), pp. 653-661, 2005.

[9] M. Malinowski, et al., "A survey on Cascaded Multilevel Inverters," IEEE Trans. on Ind. Elect., vol/issue: 57(7), pp. 2197-2206, 2010

[10] S. Kouro, et al., "Recent Advances and Industrial Applications of Multilevel Converters," IEEE Trans. on Ind. Elect., vol/issue: 57(8), pp. 2553-2580, 2010.

[11] B. C. Vinayaka and P. S. Nagendra, "Modeling and design of ffive level Cascaded H-Bridge Multilevel Inverter with DC/DC Boost Converter," Int. Journal of Engineering Reserach and Applications, vol/issue: 4(6), pp. 50-55, 2014.

[12] I. Ahmed, et al., "Simplified space vector modulation techniques for multilevel inverters," IEEE Trans. on Power Electronics, vol/issue: 21(12), pp. 8483-8499, 2016.

[13] W. A. Halim, et al., "Selective Harmonic Elimination based on Newton-raphson method for Cascaded H-bridge Multilevel Inverter," International Journal of Power Electronics and Drive Systems, vol/issue: 8(3), pp. 1193-1202, 2017.

[14] A. Moeini, et al., "Selective harmonic mitigation-pulse-width moduation technique with variable DC-link voltages in single and three-phase cascaded H-bridge inverters," IET Power Electronics, vol/issue: 7(4), pp. 924-932, 2014.

[15] M. Angulo, et al., "Level-shifted PWM for cascaded multilevel inverters with even power distribution," IEEE Power Electronics Specialists Conference, pp. 2373-2378, 2007.

[16] C. D. Townsend, et al., "Phase-shifted carrier modulation techniques for Cascaded H-Bridge multilevel converters," IEEE Trans. on Ind. Elect., vol/issue: 62(11), pp. 6684-6696, 2015.

[17] C. L. Toh and L. E. Norum, "VHDL implementation of capacitor voltage balancing control with Level-Shifted PWM for Modular Multilevel Converter," International Journal of Power Electronics and Drive Systems, vol/issue: 7(1), pp. 94-106, 2016. 
[18] C. R. Balamurugan, et al., "Control techniques for various bipolar PWM strategies of three phase five level cascaded inverter," Journal of Engineering Science and Technology, vol/issue: 10(7), pp. 878-897, 2014.

[19] “IEEE Recommended Practice and Requirements for Harmonic Control in Electric Power Systems,” IEEE, 2014.

\section{BIOGRAPHIES OF AUTHORS}

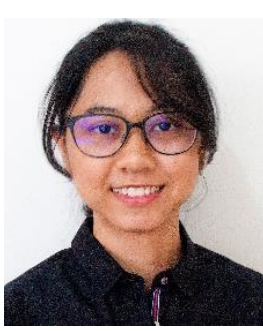

Azreen Awalludin received the B. Eng. degree in electrical power engineering from Universiti Tenaga Nasional (UNITEN), Kajang, Malaysia, in 2018. She is currently with Sime Darby Plantation Sdn Bhd as a Skim Latihan 1 Malaysia (SL1M) Trainee under Stratergy and Innovation Department.

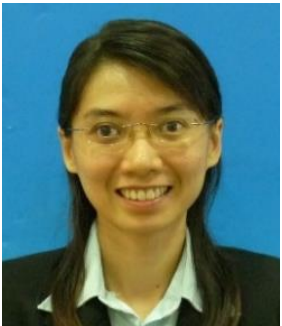

Chuen Ling Toh received the B. Eng. and M. Eng. degree in electrical engineering, both from Universiti Teknologi Malaysia (UTM), Skudai, Malaysia, in 2002 and 2005 respectively; and her Ph.D in Electrical Power Engineering from Norwegian University of Science and Technology (NTNU), Trondheim, Norway, in 2014. Currently, she is a Senior Lecturer at the Universiti Tenaga Nasional, Kajang, Malaysia. Her teaching and research interests include the field of power electronics, motor drive systems and field programmable gate array applications. She is also a Member of IEEE Power Electronics Society (PELS) Malaysia Chapter. 